\title{
국립공원의 해발고도에 따른 환경방사선 측정 Measurement of Environmental Radiation according to Altitude above Sea Level in National Park
}

\author{
지태정, 이인식 \\ 가야대학교 방사선학과 \\ Tae-Jeong Ji(tjjee@kaya.ac.kr), In-Sik Lee(ttlinsik@naver.com)
}

\section{요약}

본 연구는 국가환경방사선 자동감시망이 설치되지 않은 국립공원의 산악 지역을 대상으로 환경방사선을 측정하였다. 측정 방법은 지표 $1 \mathrm{~m}$ 높이에서 공간선량과 지표면에서의 지표선량을 측정하였다. 국립공원 선 정은 중부지역과 남부지역을 같은 분포로 하여 전국에 10 곳을 선정하였다. 측정장비는 감마선측정에 활용 되는 INTERCEPTOR ${ }^{T M}$ (Thermo, USA, 2006)를 사용하였다. 방사선측정은 국립공원 입구와 정상에서는 필수적으로 측정하였고, 그 외 지점은 해발 고도를 $500 \mathrm{~m}$ 단위로 구분하여 탐방객이 많이 다니는 곳에서 측정하였다. 측정횟수는 각 지점에서 2 분간 장비를 안정시킨 후 5 회 이상 측정하였다. 측정결과, 공간감마선 량의 경우 $1,000 \mathrm{~m}$ 이하 국립공원에서는 해발 고도 $500 \mathrm{~m}$ 지점에서 높은 선량이 측정되었다. 그 중 북한산, 계룡산, 월출산에서 $0.23 \mu \mathrm{Svh}^{-1}$ 이상인 것으로 확인되었다. $1,000 \mathrm{~m}$ 이상의 국립공원에서는 설악산 $1,500 \mathrm{~m}$ 지점에서 $1.77 \mu \mathrm{Svh}^{-1}$ 로 측정되어 백그라운드 기준 선량보다 10 배 이상 증가하였다. 선량에 유의한 변화를 보이지 않은 국립공원은 내장산, 소백산, 지리산으로 확인되었다. 환경방사선량이 낮게 측정된 산은 가야산 정상 $(1,430 \mathrm{~m})$ 에서 $0.04 \mu \mathrm{Svh}^{-1}$, 한라산 정상 $(1,950 \mathrm{~m})$ 에서 $0.03 \mu \mathrm{Svh}^{-1}$ 인 것으로 확인되었다. 지표선량 측정에 서도 중간 높이인 $500 \mathrm{~m}, 1,000 \mathrm{~m}$ 에서 높게 측정되었다. 지각 구성물질의 종류에 따른 측정에서는 암석으로 구성된 국립공원에서 높은 선량으로 조사되었으며, 화산활동이 일어났던 한라산에서는 환경방사선량이 낮 게 측정되었다.

- 중심어 : | 환경방사선 | 국립공원 | 해발고도 | 공간선량 |

\section{Abstract}

This study set put to measure the environmental radiation for mountainous regions of National Parks where Integrated Environmental Radiation Monitoring Network is not installed. For the measurement method, the space dose was classified at 1 meter high from the surface and the index dose at the surface. The measured radiation energy measured gamma, alpha and beta rays. For selection of national parks, we selected 10 national parks which are within the same distribution in the southern part and central part of the nation. For measurement equipment, INTERCEPTOR $^{T M}$ (Thermo, USA, 2006) was used for gamma rays. As for the results of the measurements, for the space gamma dose, a high level was measured at a sea level of 500 meter in national parks with an altitude of less than 1,000 meter. It was found that the value was more than $0.23 \mu \mathrm{Svh}^{-1}$ especially in Bukhan Mountain, Gyeryong Mountain and Wolchul Mountain. In national parks with an altitude of more than 1,000 meter, $1.77 \mu \mathrm{Svh}^{-1}$ was measured at 1,500 meter at Seorak Mountain. Therefore, this is 10 times greater than the background standard dose. The national parks were there were no significant changes in dose were Naejang Mountain, Sobaek and Jiri Mountains. For the measurement of the index dose, a high dose level was measured at middle altitudes of 500 meter and 1,000 meter. For measurement according to the composition types of crust, high doses were recorded at national parks composed of rocks and a lower environmental radiation level was measured at Hanra Mountain where volcanic activities have occurred.

- keyword : | Environmental Radiation | National Park | Sea Level | Space Dose |

접수번호 : \#121004-008

접수일자 : 2012년 10월 04일
심사완료일 : 2012년 11월 14일

교신저자 : 지태정, e-mail : tjjee@kaya.ac.kr 


\section{I. 서 론}

환경방사선은 생활환경 내에서 발생되는 것으로 자 연방사선과 인공방사선이 있다. 이중 인공방사선은 원 자력시설을 포함한 산업, 의료, 군사 및 연구시설 등에 서 발생되는 것으로 엄격한 기준과 법령으로 통제된다. 하지만 자연방사선은 인류와 함께 공존하는 것으로 지 각이나 대기 중에 부유하거나 음식물, 건재 등에 포함 되는데 그중 라돈가스가 가장 많은 비중을 차지하는 것 으로 보고되었다[1]. 또한 일부 인구 밀집지역의 지하수 에서 방사성물질이 검출되었으며[2], 음식물 중의 ${ }^{40} \mathrm{~K}$ 과 우라늄, 토륨 등의 붕괴에 의해 생성된 ${ }^{222} \mathrm{Rn}$ 가스가 지하시설에서 자연방사선의 허용치를 초과하여 검출된 것으로 보고되었다[3]. 2011년 일본의 원전사고로 인체 에 미치는 영향에도 관심이 증가되고 있다. 특히 원자 력 이용률이 높은 국가에서는 실시간 모니터링을 통하 여 감시 체계를 운용하고 있다. 우리나라도 원자력안전 법에 의해 국토전역에 환경방사선측정소를 설치하여 그 결과를 평가하도록 하고 있다. 현재 전국적으로 국 가환경방사선 지방측정소는 12 개, 간이방사선측정소는 36 개, 군부대와 연계된 측정소가 19 개, 원자력발전소 주 변에 4개소가 있다[4]: 하지만 대부분 도심지역을 포함 한 인구밀집 지역에 위치하고 있어 유동인구가 많은 국 립공원이나 해발고도가 높은 산악지대에는 실시간 모 니터링이 어렵고 측정 자료도 부족하다. 국립공원관리 공단의 통계자료에 의하면 국립공원의 탐방객 수는 2006년에 2,600만명에서 2010년도에는 4,200만명으로 증가하였으며, 2011년도 통계에서도 4천만명 이상 되는 것으로 나타났다. 이중 바위산으로 형성된 북한산과 해 발고도가 높은 설악산, 지리산 순으로 탐방객이 많은 것으로 조사되었다[5]. 이처럼 유동인구가 많은 지역임 에도 환경방사선에 대한 측정 자료는 미흡한 실정이다. 지금까지 보고된 자연방사선에 대한 연구에서는 암반 으로 구성된 곳에서 지각에 의한 환경방사선이 증가하 는 것으로 알려져 있으며, 해발고도가 높을수록 우주선 의 영향으로 평지에 비해 방사선수치가 높게 측정된 것 으로 보고되었다[1]. 연간 인류가 받는 자연방사선량을 유엔방사선영향과학위원회(UNSCEAR)에서는 $2.4 \mathrm{mSv}$
라고 하였으며, 그중 $\mathrm{U}^{238}$ 계열의 붕괴가 $1.24 \mathrm{mSv}$ 로 연 간 선량의 $51 \%$ 를 차지하고, 지각구성물에서 발생하는 선량은 $0.41 \mathrm{mSv}$ 로 전체 선량의 $17 \%$ 를 차지하는 것으 로 보고되었다[14]. 이처럼 환경방사선은 지리적요인, 암석과 토양의 구성 및 해발고도가 높아짐에 따라 차이 를 보이는 것으로 알려졌다. 따라서 본 연구는 특정지 역에 설치되어 있는 국가환경방사선측정소 이외의 지 역에서 일반인들의 출입이 많은 전국 국립공원을 중심 으로 해발 고도와 지각 구성 물질 및 지리적 위치에 따 른 지표선량과 지표 $1 \mathrm{~m}$ 에서 계측한 공간선량을 측정하 여 환경방사선량을 알아보고자 하였다.

\section{II. 국립공원의 선정 및 계측기 측정방법}

\section{1.국립공원 선정 및 측정기간}

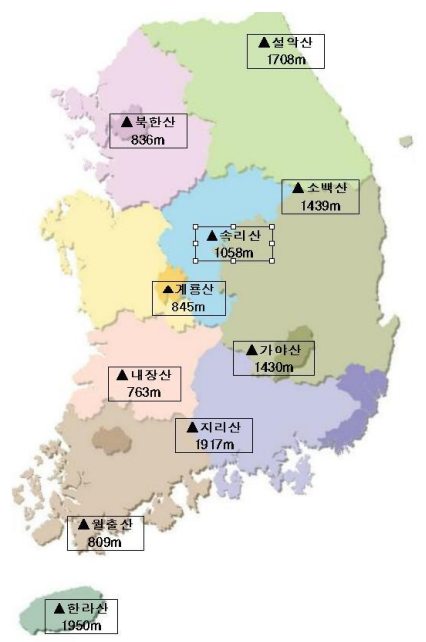

Fig. 1 The 10 National parks to measure en vironmental radiation.

환경방사선 측정을 위한 국립공원의 선정은 산악지 대에 위치한 공원을 대상으로 하였으며, 전국토의 균형 적인 측정을 위해 지리적 위치와 지형적인 형태 및 암 반 구성을 기준으로 총 10 곳을 선정하였다. 해발고도 $1,000 \mathrm{~m}$ 이상인 6 곳으로는 한라산, 지리산, 설악산, 소백 산, 가야산, 속리산을 선정하였으며, $1,000 \mathrm{~m}$ 이하인 4 곳 은 계룡산, 북한산, 내장산, 월출산으로 선정하였다. 측 
정 시기는 탐방객이 가장 많은 8월과 11 월을 기준으로 2011년 8월부터 11월까지 4개월 동안 일출 후 일몰 전 에 측정하였다. 측정을 위한 등산로는 일반인들이 많이 왕래하는 탐방로를 이용하였으며, 도보로 고도계를 보 며 측정 위치를 선정하였다[Fig. 1].

\section{2. 방사선측정장비 및 고도계}

공간 감마선측정을 위한 측정장비는 파장에 따른 에너지 분 포와 핵종 분석이 가능한 측정장비 $\mathrm{INTERCEPTOR}^{T M}$ (Thermo, USA, 2006)를 사용하였다. 측정기의 Dose range는 $10 \mathrm{nSvh}^{-1}$ 에서 $10 \mathrm{Svh}^{-1}$ 까지 등가선량으로 표시 되며, Gamma dose rate와 Neutron counter가 가능하고 $\mu \mathrm{Svh}^{-1}$ 까지 표현되는 스펙트럼 파장을 얻을 수 있는 장 비를 사용하였다. 고도계는 $5,000 \mathrm{~m}$ 까지 측정 가능한 MINGLE(China, 2011)을 사용하였다[Fig. 2].

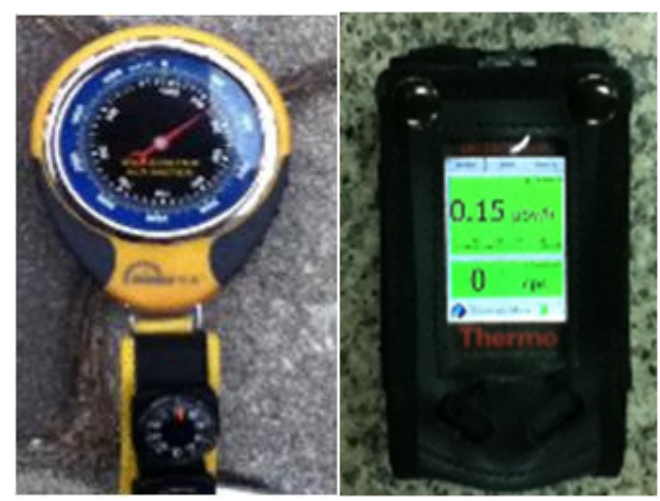

Fig. 2 The measuring instrument of gamma dose: INTERCEPTOR ${ }^{\text {TM }}$ (Thermo, USA, 2006) (left), An altimeter: MINGLE (China, 2011) (right).

\section{3. 공간선량과 지표선량의 환경방사선 측정}

공간선량 측정은 지표 $1 \mathrm{~m}$ 높이에 삼각스텐드를 설치 하고 측정장비를 스텐드 위에 고정 후 2 분간 장비를 안 정시킨 다음 5 분 간격으로 5 회 측정하였다. 지표선량은 지표면에 측정기를 위치시키고 측정하였다. 측정위치 는 국립공원의 입구(매표소)에서 측정하고, 해발고도 $500 \mathrm{~m}, 1,000 \mathrm{~m}, 1,500 \mathrm{~m}$, 정상에서 각각 측정하였다. 측정 기의 위치는 암반으로 구성된 곳은 암석위에 위치시키 고 평균 수치를 체크하는 방식으로 측정하였다.

\section{4. 통계처리 및 측정방법}

통계처리는 SPSS(Ver. 12.0)을 활용하여 5회 측정한 데이터에서 표준편차와 오차를 표시하고 Sigma Plot 8.0을 활용하여 Grouped vertical Bar 차트로 작성하였 으며, 추정된 회기계수의 $95 \%$ 신뢰수준으로 작성하였 다. 측정단위는 국제방사선방호위원회(ICRP)와 방사선 표준진료지침서(과학기술부, 2001)[10], 국제단위계(한 국표준과학연구원, 2006)에서 권고사항인 국제단위계 (SI)의 단위체계인 선량당량의 명칭인 시버트(Sievert $(\mathrm{Sv}, \mathrm{j} / \mathrm{kg})$ )를 사용하였으며[11], 이것은 흡수선량에 방 사선 하중계수를 곱한 등가선량(Equivalent dose)이다.

\section{III. 결 과}

\section{1. 공간에서의 환경방사선 측정 결과}

지표 $1 \mathrm{~m}$ 에서의 공간감마선량 측정은 해발고도 $500 \mathrm{~m}$ 단위로 구분하여 측정하였다. 측정 결과 국립공원에 따 라 유의한 차이를 보였다. $1,000 \mathrm{~m}$ 이하인 북한산, 내장 산, 계룡산, 월출산의 경우 탐방로 입구와 정상에서는 공간선량이 0.1-0.168 $\mu \mathrm{Svh}^{-1}$ 로 나타나 유의한 변화가 없 었으나 중간 부분인 해발 $500 \mathrm{~m}$ 에서는 5 회 측정한 평균 수치가 북한산이 $0.26 \mu \mathrm{Svh}^{-1}$, 계룡산이 $0.23 \mu \mathrm{Svh}^{-1}$, 월출 산이 $0.23 \mu \mathrm{Svh}^{-1}$ 로 다소 높게 측정되었으며, 내장산은 $0.13 \mu \mathrm{Svh}^{-1}$ 으로 유의한 차이를 보이지 않았다[Fig. 3]. $1,000 \mathrm{~m}$ 이상의 국립공원에서는 설악산에서 가장 높은 수치가 측정되었다. 설악산의 고도별 측정치는 $1,000 \mathrm{~m}$ 에서 $0.14 \mu \mathrm{Svh}^{-1}, 1,500 \mathrm{~m}$ 에서 $1.77 \mu \mathrm{Svh}^{-1}$, 정상 $(1,708 \mathrm{~m})$ 에서 $1.04 \mu \mathrm{Svh}^{-1}$ 로 확인되었다.

그 중 $1,500 \mathrm{~m}$ 지점에서의 측정치는 백그라운드 선량 보다 10배 높게 측정되었다[Fig. 5]. 속리산에서도 탐방 로 입구에서 $0.20 \mu \mathrm{Svh}^{-1}, 500 \mathrm{~m}$ 에서 $0.25 \mu \mathrm{Svh}^{-1}$, 정상에서 $0.17 \mu \mathrm{Svh}^{-1}$ 로 다소 높게 측정되었다. 그 외 소백산, 지리 산에서는 해발 고도에 따른 유의한 변화가 없었다. 한편 가야산과 한라산에서는 공간감마선량이 평균적으로 측 정된 선량보다 낮게 측정되었는데 가야산의 경우 $1,000 \mathrm{~m}$ 에서 $0.08 \mu \mathrm{Svh}^{-1}, 1,430 \mathrm{~m}$ 정상에서 $0.04 \mu \mathrm{Svh}^{-1}$ 가 측정되었 으며, 한라산은 $1,000 \mathrm{~m}$ 에서 $0.05 \mu \mathrm{Svh}^{-1}, 1,500 \mathrm{~m}$ 에서 $0.04 \mu$ 


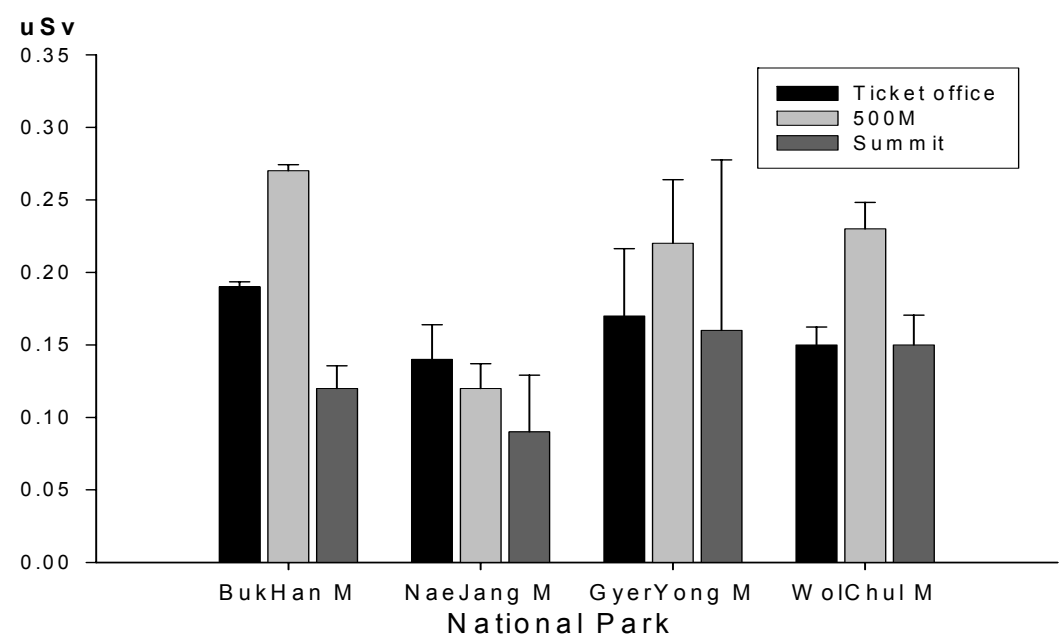

Fig. 3 Graph measured of space gamma dose according to altitude in National Park of less than $1,000 \mathrm{~m}$.

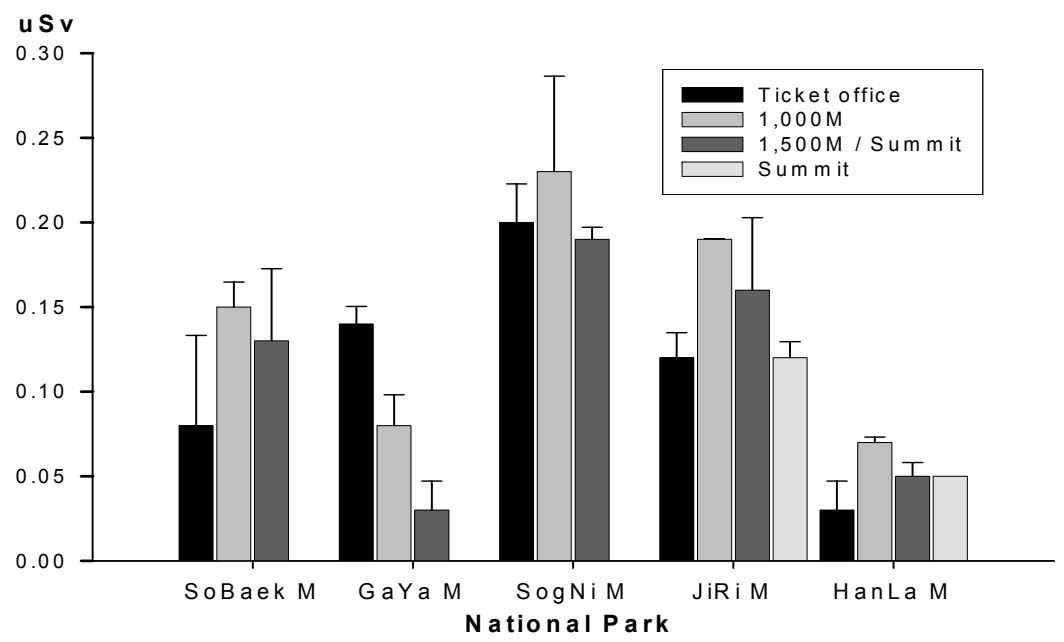

Fig. 4 Graph measured of space gamma dose according to altitude in National Park of more than $1,000 \mathrm{~m}$

$\mathrm{Svh}^{-1}, 1,950 \mathrm{~m}$ 정상에서 $0.03 \mu \mathrm{Svh}^{-1}$ 로 측정되어 백그라운 드 선량보다 낮은 것으로 확인되었다[Fig. 4].

\section{2. 지표면에서 환경방사선 측정 결과}

지표면에서의 감마선 측정 결과, 공간선량 측정값과 비교하여 유의하게 증가한 국립공원은 내장산, 월출산, 지리산으로 조사되었다. 특히 해발고도 $500 \mathrm{~m}$ 에서 측 정 선량을 보면, 내장산에서는 지표선량이 $0.17 \mu \mathrm{Svh}^{-1}$,
공간선량이 $0.13 \mu \mathrm{Svh}^{-1}$ 확인되었고, 월출산에서는 지표 선량이 $0.30 \mu \mathrm{Svh}^{-1}$, 공간선량이 $0.23 \mu \mathrm{Svh}^{-1}$, 지리산에서 는 지표선량이 $0.28 \mu \mathrm{Svh}^{-1}$, 공간선량이 $0.16 \mu \mathrm{Svh}^{-1}$ 로 측 정되어 지표선량이 공간선량에 비해 20 75\% 높게 측 정되는 것으로 나타났다[Fig. 7]. 지표선량이 가장 높게 측정된 국립공원은 설악산으로 정상인 대청봉 $(1708 \mathrm{~m})$ 에서 $0.98 \mu \mathrm{Svh}^{-1}$ 로 측정되었다. 낮은 수치를 보인 국립 공원은 한라산과 가야산이며 한라산 정상 $(1950 \mathrm{~m})$ 에서 
$0.02 \mu \mathrm{Svh}^{-1}$ 로 측정되었고, 가야산 정상 $(1430 \mathrm{~m})$ 에서는 $0.042 \mu \mathrm{Svh}^{-1}$ 로 측정되었다.

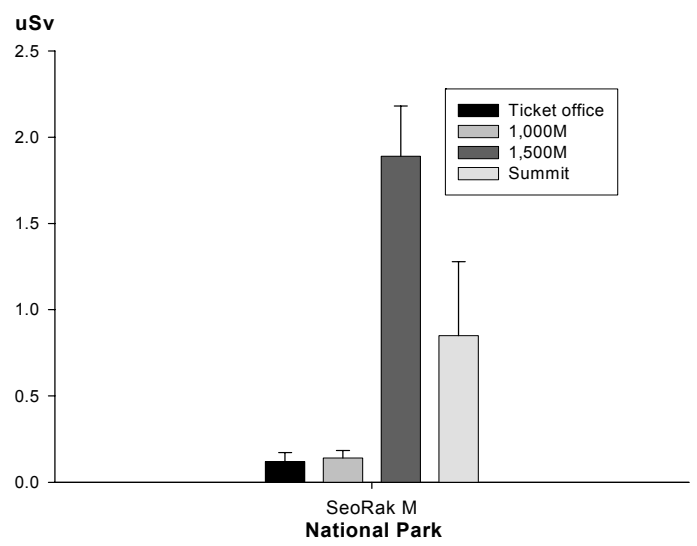

Fig. 5 Graph measured of space gamma dose according to altitude in Seorak National Park.

\section{3. 지리적 위치와 해발고도에 따른 환경방사선}

\section{측정 결과}

지리적 위치에 따른 국립공원의 공간선량 측정치를 분석하기 위해 중부지역을 설악산, 북한산, 속리산, 소 백산으로 하여 65 곳을 측정하고, 남부지역은 한라산, 지 리산, 월출산, 내장산으로 분류하여 70 곳에서 측정하였 다. 측정 결과 중부지역에서는 평균 선량이 $0.339 \mu \mathrm{Svh}^{-1}$ 로 확인되었고, 남부지역에서는 $0.112 \mu \mathrm{Svh}^{-1}$ 로 확인되 어 중부지방의 국립공원에서 3 배 정도 높은 선량이 측 정되었다. 또한 한 지점에서 5회 측정한 데이터에서 최 소치와과 최고치의 평균값을 분석해 본 결과 남부지역 에 비해 중부지역의 국립공원에서 최고치는 3.6 배 최저 치는 1.6 배 높게 측정된 것으로 확인되었다. 해발고도 에 따른 감마 선량의 차이는 $1,500 \mathrm{~m}$ 이하의 국립공원에 서는 $500 \mathrm{~m}$ 지점에서 높게 측정되었고, $1,500 \mathrm{~m}$ 이상의 국립공원에서는 $1,500 \mathrm{~m}$ 지점에서 선량이 높게 측정되 었다. 10 곳의 국립공원 중 가장 높게 측정된 곳은 설악 산 $1,500 \mathrm{~m}$ 지점에서 $1.77 \mu \mathrm{Svh}^{-1}$ 인 것으로 확인되었다 [Table 1].

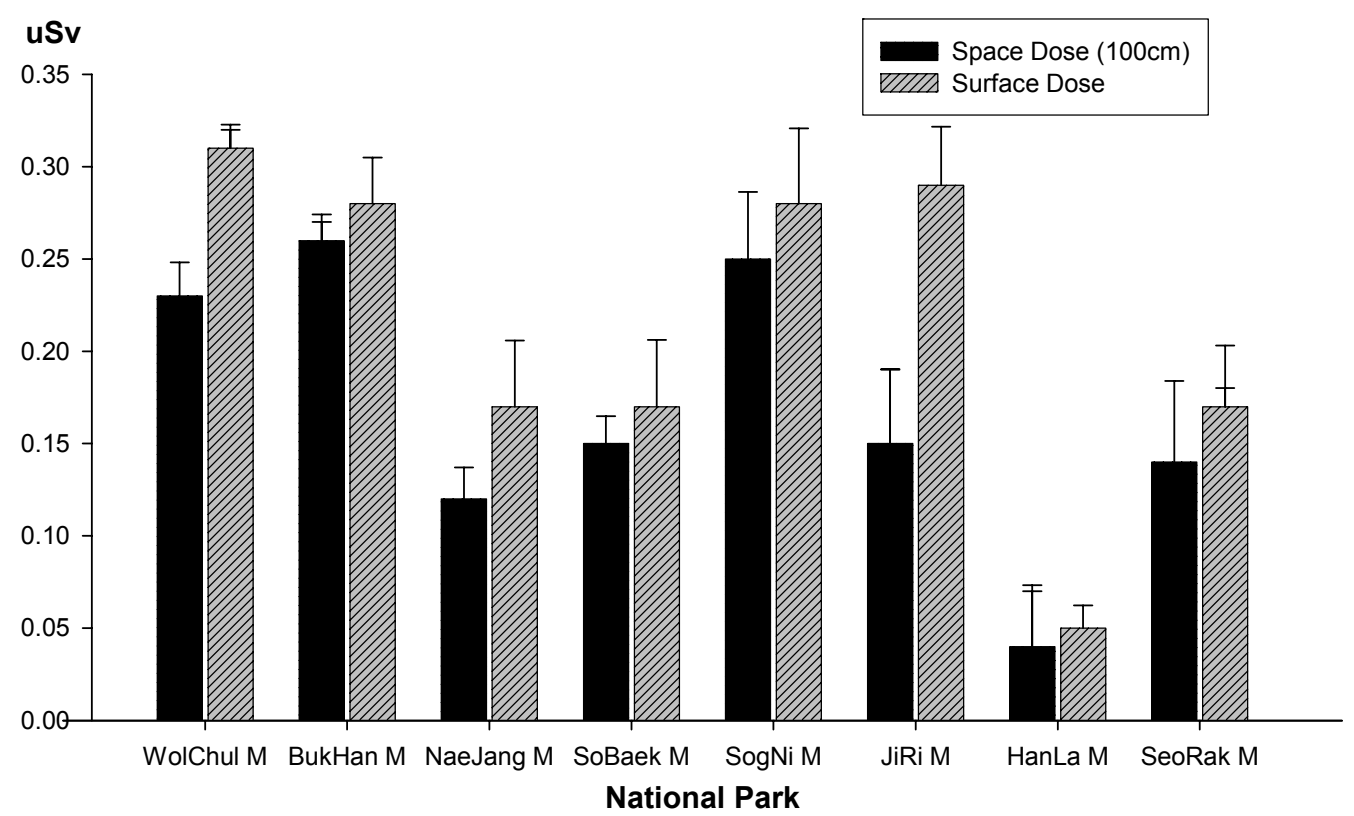

Fig. 6 Comparison of measured changes of space dose and Index dose to 500 meters above sea level. 
Table 1. Comparison of Space Gamma Dose in Central Part and Southern Part $\left(\mathrm{uSyh}^{-1}\right)$

\begin{tabular}{|c|c|c|c|c|c|c|c|c|c|c|c|}
\hline & 공원명 & 해발 고도 & 평균 감마선 & 최저치 & 최고치 & & 공원명 & 해발 고도 & 평균 감마선 & 최저치 & 최고치 \\
\hline \multirow{15}{*}{$\begin{array}{l}\text { 중부 } \\
\text { 지역 }\end{array}$} & \multirow{3}{*}{ 북한산 $(836 \mathrm{~m})$} & 매표소 & $0.17 \pm 0.02$ & 0.15 & 0.19 & \multirow{15}{*}{$\begin{array}{l}\text { 남부 } \\
\text { 지역 }\end{array}$} & \multirow{3}{*}{$\begin{array}{c}\text { 내장산 } \\
(763 \mathrm{~m})\end{array}$} & 매표소 & $0.13 \pm 0.024$ & 0.1 & 0.16 \\
\hline & & $500 \mathrm{~m}$ & $0.26 \pm 0.01$ & 0.24 & 0.27 & & & $500 \mathrm{~m}$ & $0.13 \pm 0.008^{*}$ & 0.12 & 0.14 \\
\hline & & 정상 & $0.12 \pm 0.01$ & 0.11 & 0.14 & & & 정상 & $0.10 \pm 0.023$ & 0.08 & 0.14 \\
\hline & \multirow{3}{*}{$\begin{array}{c}\text { 소백산 } \\
\text { (1439m) }\end{array}$} & 매표소 & $0.11 \pm 0.02$ & 0.08 & 0.13 & & \multirow{3}{*}{$\begin{array}{l}\text { 월출산 } \\
(809 \mathrm{~m})\end{array}$} & 매표소 & $0.15 \pm 0.008^{*}$ & 0.14 & 0.16 \\
\hline & & $1000 \mathrm{~m}$ & $0.15 \pm 0.02$ & 0.13 & 0.16 & & & $500 \mathrm{~m}$ & $0.23 \pm 0.011$ & 0.22 & 0.25 \\
\hline & & 정상 & $0.12 \pm 0.04$ & 0.09 & 0.89 & & & 정상 & $0.15 \pm 0.014$ & 0.13 & 0.17 \\
\hline & \multirow{4}{*}{$\begin{array}{c}\text { 설악산 } \\
(1708 \mathrm{~m})\end{array}$} & 매표소 & $0.15 \pm 0.09$ & 0.12 & 0.17 & & \multirow{4}{*}{$\begin{array}{c}\text { 지리산 } \\
(1916 \mathrm{~m})\end{array}$} & 매표소 & $0.11 \pm 0.02^{*}$ & 0.08 & 0.13 \\
\hline & & $1000 \mathrm{~m}$ & $0.14 \pm 0.03$ & 0.11 & 0.19 & & & $1000 \mathrm{~m}$ & $0.14 \pm 0.032$ & 0.1 & 0.19 \\
\hline & & $1500 m$ & $1.77 \pm 0.33$ & 0.23 & 2.27 & & & $1500 m$ & $0.17 \pm 0.026$ & 0.13 & 0.2 \\
\hline & & 정상 & $0.90 \pm 0.44$ & 0.16 & 1.35 & & & 정상 & $0.11 \pm 0.016$ & 0.09 & 0.13 \\
\hline & \multirow{4}{*}{$\begin{array}{c}\text { 속리산 } \\
(1058 \mathrm{~m})\end{array}$} & 매표소 & $0.20 \pm 0.02$ & 0.19 & 0.23 & & \multirow{4}{*}{$\begin{array}{c}\text { 한라산 } \\
(1950 \mathrm{~m})\end{array}$} & 매표소 & $0.04 \pm 0.008^{*}$ & 0.03 & 0.05 \\
\hline & & $750 \mathrm{~m}$ & $025+003$ & 023 & 029 & & & $1000 \mathrm{~m}$ & $0.05 \pm 0.018$ & 0.03 & 0.07 \\
\hline & & $100 \mathrm{~m}$ & $0 . \angle 5 \pm 0.03$ & 0.23 & 0.29 & & & $1500 m$ & $0.04 \pm 0.01^{*}$ & 0.03 & 0.06 \\
\hline & & 정상 & $0.17 \pm 0.03$ & 0.14 & 0.19 & & & 정상 & $0.03 \pm 0.01^{*}$ & 0.02 & 0.05 \\
\hline & \multicolumn{2}{|c|}{ 평균 } & & 0.15 & 0.49 & & \multicolumn{2}{|c|}{ 평균 } & & 0.10 & 0.14 \\
\hline
\end{tabular}

\section{4. 지각 구성 물질에 따른 환경방사선 측정 결과}

지각 구성물질에 의한 공간감마선량의 변화는 유의 한 것으로 확인되었다. 화강암 편마암 등으로 구성된 북한산, 설악산에서는 해발고도가 $500 \mathrm{~m}$ 와 $1,000 \mathrm{~m}$ 에서 $0.23 \mu \mathrm{Svh}^{-1}$ 이상으로 측정되어 일반적인 국립공원의 선 량과 비교하여 높게 측정된 것으로 확인되었다. 또한 암석으로 구성된 지역이라도 정상으로 올라갈수록 선 량이 낮게 측정된 것으로 조사되었다.

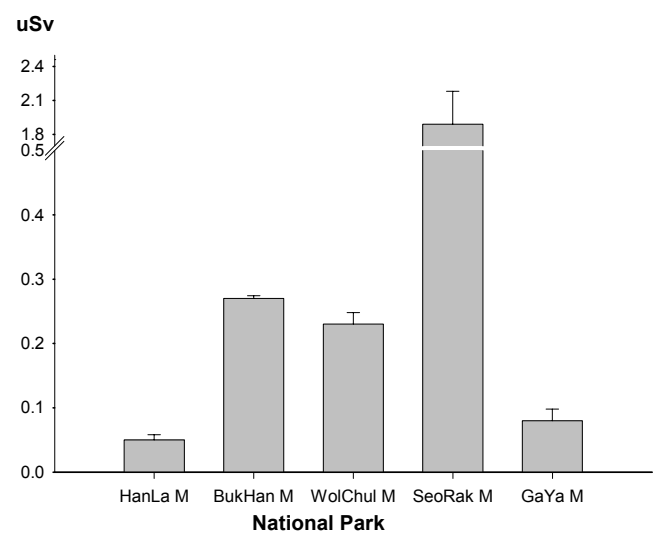

Fig. 7 Graph measured of environmental gam ma dose according to crust structure materials in National park.
한편 가야산의 경우, 암석 봉우리로 형성되었으나 선 량 측정치는 일반 국립공원 보다 낮은 수치로 측정되었 으며, 한라산의 경우에도 화산활동에 의해 형성되었지 만 백그라운드 선량보다 낮은 0.03-0.05 $\mu \mathrm{Svh}^{-1}$ 로 측정되 었다[Fig. 7].

\section{IV. 고 찰}

방사선은 지구가 생성되기 전부터 존재하고 있었으 며 인류는 방사선과 함께 생활한다고 할 수 있다. 국가 환경방사선 자동감시망(IERNet)을 운용하고 있는 원자 력안전기술원에서는 2011년도 연평균 공간감마선량률 이 고산 $6.9 \mu \mathrm{Rh}^{-1}$ 속초 $18.6 \mu \mathrm{Rh}^{-1}$ 범위내에서 지역별 로 차이가 나는 것은 지각성분인 암석, 토양에 함유된 우라늄계열, 토륨계열의 지각방사선의 준위가 결정되기 때문이라고 하였으며, 연 평균값을 $11.9 \mu \mathrm{Rh}^{-1}$ (또는 $0.119 \mu \mathrm{Svh}^{-1}$ 라고 하였다[8][9]. 본 연구에서도 평균적으 로 $0.08 \sim 0.16 \mu \mathrm{Svh}^{-1}$ 범위에서 측정된 것으로 조사되었다. 또한 지 등이 보고한 공동주택 주변의 공간감마선량률의 연구에서도 생활환경에서 측정되는 선량을 $0.09 \sim 0.15 \mu$ $\mathrm{Svh}^{-1}$ 라고 보고하였다[6]. 하지만 방사성 물질은 대기 
상태나 환경변화에 따라 이동하기 때문에 방사선 관련 사고시 지역에 따라 차이가 있을 수 있다. 또한 지각의 구성물질에 따라서도 변할 수 있다. 이와 같은 위험도 는 2011년 동일본 원전사고에서도 방사성 물질이 한자 리에 머물러 있지 않고 환경적 영향에 따라 이동하는 것으로 알려지면서 생활방사선에 대한 영향이 증가되 고 있다[7]. 더욱이 지리적으로 인접지역에 위치하고 있 는 우리나라는 대기흐름에 따라 일정 부분 영향을 받을 수 있는 것으로 보고되었다[12][13]. 특히 지대가 높은 곳에 위치한 국립공원의 경우 환경방사선의 측정은 실 시간 모니터링이 필요하지만 산악지역의 특성상 자동 감시망을 운영하지 않고 있다. 본 연구는 이러한 예외 지역을 중심으로 탐방객이 많은 8월에서 11월까지 일 반인들이 많이 방문하는 국립공원 10 곳을 선정하여 환 경방사선 측정을 실시하였다. 연구결과 $1,000 \mathrm{~m}$ 이하의 국립공원 4 곳 중 북한산, 계룡산, 월출산 $500 \mathrm{~m}$ 지점에 서 계측한 공간감마선량이 평균 $0.23 \mu \mathrm{Svh}^{-1}$ 이상 측정 되었다. 또한 $1,000 \mathrm{~m}$ 이상의 국립공원에서는 6 곳 중 설 악산 $1,500 \mathrm{~m}$ 지점에서 $1.77 \mu \mathrm{Svh}^{-1}$, 정상 $(1,708 \mathrm{~m})$ 에서 $1.04 \mu \mathrm{Svh}^{-1}$ 로 측정되어 백그라운드 선량보다 10 배 높 은 것으로 확인되었다. 또한 해발고도가 높은 국립공원 에서 높게 측정된 것을 알 수 있었으며, $1,000 \mathrm{~m}$ 이하의 국립공원에서도 중간높이의 지점에서 백그라운드 선량 보다 높은 것으로 확인되었다. 이러한 결과는 한국원자 력안전기술원에서 보고한 2010년 2011년 전국환경방사 능조사 보고서[8][9] 자료와 비교해 본 결과 일부 차이가 있는 것으로 확인되었다. 보고서에서는 2010년도 10월 평균 공간감마선량률이 고산 $6.9 \mu \mathrm{Rh}^{-1}$, 속초 $18.8 \mu \mathrm{Rh}^{-1}$ 로 보고되었고, 2011년 10월 평균 선량은 고산 7.0 $\mathrm{Rh}^{-1}$, 속 초 $19.4 \mu \mathrm{Rh}^{-1}$ 로 속초지역에서 조금 높은 것으로 나타났 다. 본 연구 결과에서는 2011년 10월 측정한 설악산 $1,500 \mathrm{~m}$ 지점에서의 선량이 $1.77 \mu \mathrm{Svh}^{-1}$ 로 측정되어 같은 단위로 환산하면 $177 \mu \mathrm{Rh}^{-1}$ 가 되어 2010년도 원자력안 전기술원에서 발표한 보고서와 비교하여 10 배 높은 수 치가 측정된 것이다. 이는 2009년 국기위기관리기본지 침의 “원자력분야 위기징후 운영 및 평가지침”에 따라 $1,000 \mathrm{nSvh}^{-1}$ (또는 $100 \mu \mathrm{Rh}^{-1}$ ) 이상의 비상준위에서는 방 사능방제대책의 이행과 필요한 주민보호조치를 취하도
록 해야 하는 수치이다[8]. 또한 본 연구에서 높은 수치 를 보인 원인에 대해서는 추가적인 연구가 필요해 보이 지만 2011년 3월에 발생된 동일본지역의 후쿠시마 원전 사고를 무시할 수 없을 것으로 사료된다. 따라서 기상변 화에 따른 방사성물질이 한반도에 영향을 주었다는 것 에 비중을 두고 좀 더 연구해 볼 필요가 있을 것이다.

\section{V. 결 론}

본 연구결과 국립공원에서 자연방사선은 해발고도, 지역적인 위치 및 지각의 구성 물질과 관련되어 선량이 변하는 것으로 조사되었다. 하지만 화산활동이 일어났 던 곳에서는 평균 선량보다 낮게 측정되어 다음과 같은 결론을 얻었다.

1. 지리적으로 중부지역에 위치한 설악산, 북한산, 속 리산, 소백산의 국립공원이 남부지역의 한라산, 지 리산, 월출산, 내장산의 평균선량 보다 환경감마선 량이 3 배 정도 높게 측정된 것으로 확인되었다.

2. 설악산에서 $1,500 \mathrm{~m}$ 지점 이상에서 백그라운드 선 량보다 10 배 이상 높게 측정된 것에 대해서는 추 가적인 연구 분석과 계속적인 모니터링이 필요해 보인다.

3. 지각 구성 물질이 암석으로 구성된 국립공원에서 선량이 높게 측정되었으며, 화산활동이 일어났던 국립공원에서는 백그라운드 선량보다 낮게 측정 되어 화산활동과 선량변화의 유의점은 없었다.

따라서 본 연구결과 일부 국립공원에서는 매우 높은 환경방사선이 측정되어 지속적인 모니터링과 간이측정 소 설치도 고려해야 할 것이다. 또한 탐방객에 대한 교 육이 필요할 것으로 사료된다.

\section{참 고 문 헌}

[1] E. J. Hall and A. J Giaccia, Radiobiology for the radiologist, 6th ed, LWW. USA, pp.187-219, 
2006.

[2] Y. Y. Youn, S. Y. Cho, K. Y. Lee, and Y. J. KIM, "The Study of Radon and Uranium Distribution in the Groundwater at Regional Difference of Daejeon," J. korea Asso, Radiat Prot, Vol.31, No.1, pp.25-30, 2006.

[3] J. S. Jeon and D. C. Kim, "Distribution of Rn222 Concentration in Seoul Subway Stations," J. korean Soc of Environmental Engineers, Vol.28, No.6, pp.588-595, 2006.

[4] http://iernet.kins.re.kr

[5] Http://main.knps.or.kr/general/parkutil/view.do? nttid=10958\&bbsid=statistics\&g_parkcd=\&page $=20 \&$ keyword $=\&$ keyfield $=$

[6] 지태정, 곽병준, 민병인, "콘크리트 공동주택과 근 린생활 시설의 환경방사선에 관한 연구”, 한국안 전학회지, 제24권, 제2호, pp.100-104, 2009.

[7] http://blog.daum.net/jslenginc/1934691

[8] 한국원자력안전기술원, 전국환경방사능조사 2010년 기관고유사업보고서 전국환경방사능감시, KINS/ ER-028, Vol.42, 2010.

[9] 한국원자력안전기술원 전국환경방사능조사 2011년 기관고유사업보고서 전국환경방사능감시, KINS/ ER-028. Vol, 43, 2011.

[10] 과학기술부, 방사선 표준진료 지침서, 과학기술 부, pp.119-156, 2001.

[11] 한국표준과학연구원, 국제단위계(SI), 8판, 2007.

[12] 이재기, 후쿠시마원전사고로 인한 국내방사선 영향: 방사선과 안전기준, 대한방사선방어학회, pp.13-36, 2011.

[13] 한겨레신문, 남부지역 흙에서 후쿠시마발 세슘, 2012. 05.29 11면, 2012.

[14] 이상석, 박영선, 김흥태, 고성진, 의료방사선생물 학, 정문각, pp.25-31, 2003.

\section{저 자 소 개}

지 태 정(Tae-Jeong $\mathrm{Ji})$

정회원

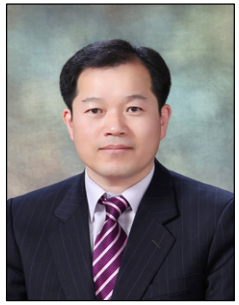

- 2006년 8월 : 국립안동대학교 생 명과학과 동물학전공(이학석사. 박사)

- 1998년 2003년 : 안동과학대, 대구보건대, 안동대학교 외래교 수

- 2007년 9월 : 식품의약안전청 의료기기위원회 안전분 과위원

- 2006년 7월 : 의생명과학회 학술이사

- 2006년 9월 : 대한방사선과학회 상임이사

- 2009년 10월 : 대한방사선학과교수협회 총무이사

- 2004년 현재 : 가야대학교 방사선학과 교수

<관심분야> : 생체조직의 방사선방어기전, 환경방사선

이 인 식(In-sik Lee)

준회원

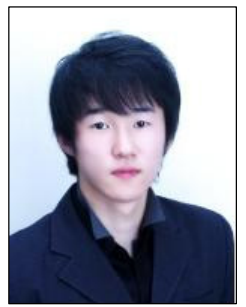

- 2012년 : 가야대학교 방사선학과 <관심분야> : 방사선 기술과 산 업 생산 